\title{
SURGICAL TREATMENT OF FRACTURES OF THE ANKYLOSED SPINE
}

\author{
TRATAMENTO CIRÚRGICO DE FRATURAS DA COLUNA ANQUILOSADA \\ TRATAMIENTO QUIRÚRGICO DE LAS FRACTURAS EN LA COLUMNA ANQUILOSADA
}

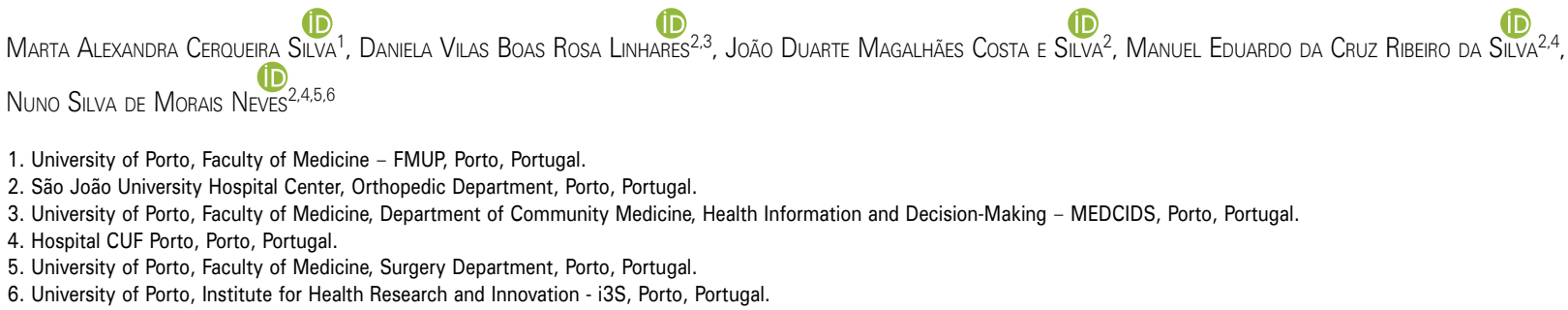

\begin{abstract}
Objective: We aim to identify retrospectively surgically treated patients with an ankylosed spine who sustained a vertebral fracture. Our goal is to evaluate the main outcomes and complications. Methods: We selected patients through the database of surgical interventions in the setting of fractures of an ankylosed spine segment between January 1st 2008 and June 30th 2018. We collected data from digital medi$\mathrm{cal}$ records. The parameters analyzed include hospital length of stay, Intensive Care Unit (ICU) admission, perioperative and postoperative complications as well as neurological evolution. Results: Fractures occurred in 14 patients with ankylosing spondylitis (82\%) and 3 patients with diffuse idiopathic skeletal hyperostosis (18\%). All patients were male and the mean age was 69 years. Fourteen fractures occurred after minor trauma $(83 \%)$, of which 11 were due to falls from standing height or lower $(65 \%)$. The cervical spine represents the majority of the levels involved (65\%). Seven patients were admitted to the ICU (41\%) and 11 suffered neurological damage. There was improvement of neurological status in less than $50 \%$ and there were high percentages of post-operative complications. Conclusion: Patients with ankylosed spine diseases are at higher risk for vertebral fracture, even after minor trauma, and these are located predominantly in the cervical spine. The surgical treatment of these conditions is effective as it allows improvement of the patient's neurological status. However, they still present higher morbidity and mortality, as well as increased post-op complications. Prevention of falls may drastically change patients' outcome, neurological function and independence in activities of daily living. Level of evidence IV; A case series therapeutic study.
\end{abstract}

Keywords: Spondylitis, Ankylosing; Hyperostosis, Diffuse Idiopathic Skeletal; Spine; Spinal Fractures.

\section{RESUMO}

Objetivo: Identificar retrospetivamente casos de tratamento cirúrgico de fraturas vertebrais em pacientes com coluna anquilosada. O nosso propósito consiste em avaliar os principais desfechos e respectivas complicações. Métodos: Selecionamos pacientes através do banco de dados de intervenções cirúrgicas no quadro de fraturas de um segmento da coluna anquilosada entre 1 de janeiro de 2008 a 30 de junho de 2018. Coletamos os dados a partir dos prontuários médicos digitais. Os parâmetros analisados incluem período de internação hospitalar, admissão na Unidade de Tratamento Intensivo (UTI), complicações pré- e pós-operatórias, assim como evolução neurológica. Resultados: As fraturas ocorreram em 14 pacientes com espondilite snquilosante (82\%) e em 3 pacientes com hiperostose esquelética difusa idiopática (18\%). Todos os pacientes eram do sexo masculino e a idade média era de 69 anos. Quatorze fraturas ocorreram devido a trauma menor (83\%), das quais 11 eram devido a quedas da própria altura ou inferiores (65\%). A coluna cervical representa a maioria dos níveis envolvidos (65\%). Sete pacientes foram admitidos na UTI (41\%) e 11 sofreram lesão neurológica. Houve melhoria do estado neurológico em menos de metade dos pacientes e altas porcentagens de complicações pós-operatórias. Conclusão: Os pacientes com doenças da coluna anquilosada têm maior risco de fraturas vertebrais, mesmo após trauma menor, localizando-se predominantemente na coluna cervical. O tratamento cirúrgico dessas condições é eficaz, uma vez que permite melhora do estado neurológico do paciente. Entretanto, ainda apresentam altos índices de morbilidade e mortalidade, assim como maior incidência de complicações pós-operatórias. A prevenção de quedas pode alterar drasticamente o desfecho, função neurológica e independência nas atividades diárias do paciente. Nível de evidência IV; Estudo terapêutico de série de casos.

Descritores: Espondilite Anquilosante; Hiperostose Esquelética Difusa Idiopática; Coluna Vertebral; Fraturas da Coluna Vertebral.

\section{RESUMEN}

Objetivo: Identificar retrospectivamente casos de tratamiento quirúrgico de fracturas vertebrales en pacientes con columna anquilosada. Nuestro propósito consiste en evaluar sus principales resultados y respectivas complicaciones. Métodos: Seleccionamos pacientes mediante banco de datos de intervenciones quirúrgicas en el cuadro de fracturas de un segmento de la columna anquilosada entre el 1 de enero de 2008 al 30 de junio de 2018. Recolectamos los datos a partir de los prontuarios médicos digitales. Los parámetros analizados incluyen período de internación hospitalaria, admisión en la Unidad de Tratamiento Intensivo (UTI), complicaciones pre y postoperatorias, 
así como evolución neurológica. Resultados: Las fracturas ocurrieron en 14 pacientes con espondilitis anquilosante (82\%) y en 3 pacientes con hiperostosis esquelética difusa idiopática (18\%). Todos los pacientes eran del sexo masculino y la edad promedio era de 69 años. Catorce fracturas ocurrieron debido a trauma menor (83\%), de las cuales 11 eran debido a caídas de la propia altura o inferiores (65\%). La columna cervical representa la mayoría de los niveles implicados (65\%). Siete pacientes fueron admitidos en la UTI (41\%) y 11 sufrieron lesión neurológica. Hubo mejora del estado neurológico en menos de la mitad de los pacientes y altos porcentajes de complicaciones postoperatorias. Conclusión: Los pacientes con enfermedades de la columna anquilosada tienen mayor riesgo de fracturas vertebrales, incluso después de trauma menor, localizándose predominantemente en la columna cervical. El tratamiento quirúrgico de esas condiciones es eficaz, ya que permite mejora del estado neurológico del paciente. Entretanto, aún presentan altos índices de morbilidad y mortalidad, así como mayor incidencia de complicaciones postoperatorias. La prevención de caídas puede alterar drásticamente los resultados, función neurológica e independencia en las actividades diarias del paciente. Nivel de evidencia IV; Estudio terapéutico de serie de casos.

Descriptores: Espondilitis Anquilosante; Hiperostosis Esquelética Difusa Idiopática; Columna Vertebral; Fracturas de la Columna Vertebral.

\section{INTRODUCTION}

Progressive ankylosis of the spine is a hallmark of two distinct diseases: ankylosing spondylitis (AS) and diffuse idiopathic skeletal hyperostosis (DISH). ${ }^{1}$ AS affects the axial skeleton, causing not only inflammation but also ossification of the end plates, discs, ligaments and apophyseal joints. It induces the development of syndesmophytes leading to a "bamboo-spine" appearance and a consequently deformed and rigid spine. ${ }^{2}$ This stiffness renders the spine prone to fracture ${ }^{3}$ and even minor traumas, like simple falls, can have catastrophic consequences, even leading to death in severe cases. ${ }^{4}$

In fact, cervical spine fractures are three times more frequent in patients with AS. Fractures in the ankylosed segments are often unstable because of the ossification of supportive and elastic soft tissues. These are more prone to dislocation with associated neurologic deficits. Moreover, even though patients may be initially neurologically intact, secondary neurologic deterioration is common due to unprotected transfers and inadequate manipulation. Also, clinical outcomes are worse in patients with ankylosed spine segments compared to the general population. ${ }^{2}$

Adequate health measures are needed in AS patient to reduce potential morbidity. Fall prevention is a mainstay, and policies need to be implemented on a large scale, engaging patients and their families. ${ }^{5}$ Additionally, since only one out of every three or four cases presents with typical signs or symptoms of spine fractures, these fractures are repeatedly misdiagnosed. ${ }^{2}$ Therefore, new back pain in patients with AS or DISH should be assumed to be caused by a fracture until proven otherwise. Thus, systematic assessment through clinical history and radiology imaging needs to be implemented and repeated for the first few weeks after a trauma, especially if the patient complains of indefinable pain, or if neurological deficits are recorded.

Although there is evidence to suggest that, like AS patients, patients with spinal ankylosis due to DISH are also at risk for unstable fractures of the spine, we realized that the awareness of DISH is much lower among clinicians. ${ }^{6,7}$ Treatment of spinal fractures in the ankylosed spine is controversial. There are several reports on nonsurgical treatment that describe it as safe compared to operative management, due to the higher morbidity and mortality rates of the latter. However, more recent studies have shown better outcomes in surgically-treated patients, ${ }^{6,7}$ with lower complication and mortality rates and higher chances of neurological improvement. ${ }^{8}$ Nonetheless, the surgical approach is very demanding, especially in the cervical spine. It can be performed successfully by different means, and should be individualized for each patient, depending on the clinical evolution and the surgeon's experience. All approaches can be safe and successful, provided the characteristics of the patients and the lesions are taken into consideration. ${ }^{9}$ Concomitant anterior and posterior stabilization is usually the chosen approach, as it provides the best support for a rigid, unstable spine. However, one must take into account associated cardiovascular and pulmonary comorbidities, which can limit the feasibility of a combined approach. ${ }^{10}$ The aim of our study is to evaluate the outcomes and complications in surgically treated patients with ankylosed spine who have sustained a vertebral fracture.

\section{METHODS}

We performed a retrospective assessment in our specialized spine trauma unit. We included all patients submitted to surgery to set a traumatic vertebral fracture of an ankylosed vertebral segment, from January 2008 to June 2018. We gathered data on demographics - sex, age, mechanism of injury, fracture level involved, delay between trauma and surgery, and comorbidities (cardiac disease, diabetes, polytrauma, closed head injury and lung disease). For each surgery, we recorded the approach used and the spine levels of fusion. We also looked for functional and neurologic data at presentation (pre-operatively) and at discharge (post-operatively), based on the American Spinal Injury Association (ASIA class), ${ }^{11}$ bowel and bladder dysfunction, discharge from hospital, ambulatory status, pain level, availability of follow-up, lost to follow-up and modified Rankin Scale score (mRS). ${ }^{12}$ Follow-up was conducted through subsequent medical appointments. Major complications were recorded as those occurring during the post-operative hospital stay.

This study was performed with the approval of the Comissão de Ética para a Saúde do Centro Hospitalar de São João (CHSJ)/ Faculdade de Medicina da Universidade do Porto (FMUP) [Health Ethics Committee of the São João Hospital Centre] - request 295/18. There was no indication for Consent Forms.

\section{RESULTS}

\section{Patients Demographics}

We identified 17 patients, all male (100\%), with fractures in an ankylosed spine treated surgically. Fourteen patients presented ankylosing spondylitis (82\%) and three DISH (18\%). The mean age at presentation was 69 years old (range from 47 to 87 ). Fifty-nine percent of patients had associated comorbidities, 7 had heart disease. (Table 1) One patient was newly diagnosed with an ankylosing syndrome at the time of the fracture. Twelve patients were completely independent in their daily activities prior to the fracture $(71 \%)$, while 5 required some degree of daily assistance (29\%). (Table 2) None of the patients was hospitalized at the time of the accident.

\section{Injury Characteristics}

Most fractures occurred after minor trauma $(n=14,83 \%)$. Eleven fractures occurred as a result of falls from standing height or even lower

Table 1. Patients' demographic characteristics.

\begin{tabular}{c|c}
\hline & n (\%) \\
\hline Male & $17(100)$ \\
\hline Median age, years [range] & $69[47-87]$ \\
\hline \multicolumn{2}{c}{ Ankylosis syndrome } \\
\hline DISH & $3(18)$ \\
\hline \multicolumn{2}{c}{ Comorbidities } \\
\hline Ankylosing spondylitis & $14(82)$ \\
\hline Cardiac disease & $7(41)$ \\
\hline Diabetes & $5(29)$ \\
\hline Lung disease & $3(18)$
\end{tabular}

DISH, diffuse idiopathic skeletal hyperostosis. 
(65\%). Three fractures resulted from a motor vehicle collision. Seven falls (41\%) lead to closed head injury, 4 fractures occurred in patients who suffered a fall from higher than their standing height. (Table 3)

The cervical spine was affected in 11 patients (65\%), the thoracic spine in three (18\%) and the cervicothoracic junction in 3 cases (18\%). (Table 3)

\section{Hospital Length of Stay and Surgical Approach}

One patient was referred to surgical treatment upon failure of initial conservative treatment (Patient \#8, Appendix). The mean length of stay was of 52 days (range 5-310). Seven patients required treatment in intensive care unit facilities (41\%). The mean period between injury and surgery was 14 days (range 0-80 days). Nine patients were submitted to spine stabilization through a posterior approach (53\%), and in 5 patients, a combined approach was chosen (29\%.) (Appendix)

\section{Neurological Deficits}

Two patients were previously ASIA D and no de novo deficits were recorded. Of the 11 patients that presented preoperative neurological deficits (ASIA A-D), 7 had no motor or sensory function in the sacral segments (41\%) and 4 presented some motor function

Table 2. Comparison of ambulatory status and functional abilities before fracture and after surgery, discharge and follow-up.

\begin{tabular}{|c|c|c|}
\hline & $\begin{array}{c}\text { Prior to injury } \\
n(\%)\end{array}$ & $\begin{array}{c}\text { Postoperative } \\
\mathrm{n}(\%)\end{array}$ \\
\hline Ambulatory status & $n=17$ & $n=14$ \\
\hline Independent & $12(71)$ & $6(43)$ \\
\hline Assistance required & $5(29)$ & $8(57)$ \\
\hline \multicolumn{3}{|c|}{ Pain Level $(n=14)$} \\
\hline None & - & $14(82)$ \\
\hline Non-limiting pain & - & $3(18)$ \\
\hline Limiting pain & - & $0(0)$ \\
\hline \multicolumn{3}{|c|}{ mRS Scale $(n=14)$} \\
\hline 0 & $10(59)$ & $6(35)$ \\
\hline 1 & $2(12)$ & $0(0)$ \\
\hline 2 & $2(12)$ & $2(12)$ \\
\hline 3 & $3(18)$ & $3(18)$ \\
\hline 4 & $0(0)$ & $0(0)$ \\
\hline 5 & $0(0)$ & $3(18)$ \\
\hline 6 (deceased) & - & $3(18)$ \\
\hline Poor outcome (mRS 4-6) & - & $6(35)$ \\
\hline \multicolumn{3}{|c|}{ Discharge From Hospital } \\
\hline Home (with or without assistance) & - & $7(41)$ \\
\hline Acute rehabilitation & - & $6(35)$ \\
\hline Skilled facility & - & $2(12)$ \\
\hline Deceased & - & $3(21)$ \\
\hline
\end{tabular}

mRS, modified Rankin Scale.

Table 3. Injury characteristics: trauma mechanism and fracture level involved.

\begin{tabular}{c|c}
\multicolumn{2}{c}{ Trauma Mechanism } \\
\hline Fall from standing height or lower & $11(65 \%)$ \\
\hline Fall from more than standing height & $3(18 \%)$ \\
\hline Low-speed motor vehicle collision & $1(6 \%)$ \\
\hline High-speed motor vehicle collision & $2(12 \%)$ \\
\hline Polytrauma & $1(6 \%)$ \\
\hline Closed head injury & $7(41 \%)$ \\
\hline Fracture Level Involved \\
\hline Occipitocervical junction & $0(0 \%)$ \\
\hline Cervical spine & $11(65 \%)$ \\
\hline Cervicothoracic junction & $3(18 \%)$ \\
\hline Thoracic spine & $3(18 \%)$ \\
\hline Thoracolumbar junction & $0(0 \%)$ \\
\hline Lumbosacral spine & $0(0 \%)$ \\
\hline
\end{tabular}

preservation below the neurological level (i.e. most key muscles had a motor score of 3 or above) (24\%). (Table 4)

In the postoperative period, 5 out of 7 patients ranked ASIA A showed no neurological improvement. In addition, no deterioration was recorded in ASIA E patients. An overall rate of improvement of $44 \%(n=4)$ was recorded after the surgical procedure, and two ASIA $\mathrm{D}$ patients became free of deficits (12\%). (Table 5)

\section{Outcomes}

Three patients died after the surgical procedure (18\%). Of those remaining, six remain independent (35\%, mRS 0) (Table 2).

Fifty-three percent of patients had some type of major complication. Eight individuals had dysautonomic episodes and 9 suffered from respiratory tract infections. Reoperation was needed in $24 \%$ and re-hospitalization in $29 \%$. Four patients complained of chronic postoperative pain (29\%). (Table 6)

The median follow-up days after discharge was 69 days and 5 patients were lost to follow-up, either because they did not attend the scheduled medical appointments or because they were transferred to another hospital. After discharge, 7 out of 13 patients were discharged to their homes, with or without assistance (41\%). Six patients entered a specialized rehabilitation program (35\%) and 2 patients were transferred to a skilled facility $(12 \%)$.

\section{DISCUSSION}

Patients with ankylosed spines, such as that seen in AS and $\mathrm{DISH}$, are at high risk of falls. Due to the nature of the ankylosed spine, they are more susceptible to spinal fractures than the general population, even after minor trauma. ${ }^{13}$

In our sample, falls from standing height or lower accounted for $65 \%$ of the spinal fractures recorded. Westerveld et al. reported similar data, with $64.3 \%$ of spine fractures occurring as a result of a low-energy trauma. ${ }^{1}$ This contrasts with the general population, with ground-level falls being responsible for only $12.9 \%^{14}$ to $20 \%^{15}$ of spine fractures.

Sapkas et al. ${ }^{10}$ found that $45 \%$ of AS spine fractures occurred in the thoracic spine and 35\% in the cervical region. In our setting, the cervical spine was the most commonly injured segment, sustaining $65 \%$ of the lesions $(n=11)$.

Since spine fractures in these patients tend to be more severe, neurologic injury is more frequent than in general population.

Table 4. Neurologic evolution, including autonomic dysfunction.

\begin{tabular}{|c|c|c|}
\hline \multicolumn{3}{|c|}{ Change of the Neurologic Deficit $(n=9) n(\%)$} \\
\hline Improvement & \multicolumn{2}{|c|}{$4(44)$} \\
\hline No improvement & \multicolumn{2}{|c|}{$5(56)$} \\
\hline ASIA class & $\begin{array}{c}\text { Preoperatively } \\
\text { n (\%) }\end{array}$ & $\begin{array}{c}\text { Postoperatively } \\
\mathrm{n}(\%)\end{array}$ \\
\hline A & $7(41)$ & $5(29)$ \\
\hline B & $0(0)$ & $1(6)$ \\
\hline C & $0(0)$ & $1(6)$ \\
\hline $\mathrm{D}$ & $4(24)$ & $2(12)$ \\
\hline E (no neurological deficit) & $6(35)$ & $8(47)$ \\
\hline Bowel dysfunction & - & $6(35)$ \\
\hline Bladder dysfunction & - & $8(47)$ \\
\hline
\end{tabular}

Table 5. Neurologic status before and after surgical according to ASIA grade.

\begin{tabular}{c|c|c|c|c|c|c}
\hline \multicolumn{7}{c}{ Postoperatively } \\
\hline \multirow{4}{*}{ Preoperatively } & ASIA n (\%) & A & B & C & D & E \\
\cline { 2 - 8 } & A & $5(29)$ & $1(6)$ & $1(6)$ & - & - \\
\cline { 2 - 8 } & D & - & - & - & $2(12)$ & $2(12)$ \\
\cline { 2 - 8 } & E & - & - & - & - & $6(35)$ \\
\hline
\end{tabular}

ASIA, American Spinal Injury Association. 
Table 6. Postoperative complications $(n=14)$.

\begin{tabular}{|c|c|}
\hline & n (\%) \\
\hline Respiratory tract infection & $9(64)$ \\
\hline Dysautonomia & $8(57)$ \\
\hline Re-institutionalisation & $5(36)$ \\
\hline Surgical reintervention & $4(29)$ \\
\hline Moderate to limiting pain & $4(29)$ \\
\hline Death & $3(21)$ \\
\hline Pneumonia & $3(21)$ \\
\hline Wound dehiscence & $3(21)$ \\
\hline Wound infection & $3(21)$ \\
\hline UTI & $3(21)$ \\
\hline Ventilator dependence & $3(21)$ \\
\hline Seizures & $3(21)$ \\
\hline Anemia & $3(21)$ \\
\hline Productive cough & $2(14)$ \\
\hline Septic shock & $2(14)$ \\
\hline Tracheobronchitis & $2(14)$ \\
\hline Hypotension & $2(14)$ \\
\hline Dysphagia & $2(14)$ \\
\hline Respiratory insufficiency & $2(14)$ \\
\hline latrogenic esophageal rupture & $2(14)$ \\
\hline Need for traqueostomy & $2(14)$ \\
\hline Fever & $1(7)$ \\
\hline Behavior changes & $1(7)$ \\
\hline Decubitus ulcer & $1(7)$ \\
\hline Depressive disorder & $1(7)$ \\
\hline Cervical osteomyelitis & $1(7)$ \\
\hline Diarrhea & $1(7)$ \\
\hline Acute Myocardial Infarction & $1(7)$ \\
\hline
\end{tabular}

UTI, urinary tract infection.

Westerveld et al. ${ }^{1}$ found that $57.1 \%$ of patients with AS and $30 \%$ with DISH suffered some type of neurologic deficit compared with $19.8 \%$ in control subjects. This corroborates our results, since $65 \%$ of our patients presented neurologic deficits. This neurological injury can have a delayed presentation during the time spanning the injury and surgical procedure. In our setting, this delay had a mean time of 14 days. An issue for discussion is that since most of these patients suffer from chronic back pain, their new post-traumatic pain may sometimes be neglected, which, along with the triviality attributed to the minor traumatic events, can lead to misdiagnosis of associated neurologic injuries. When it comes to improvement of the neurologic deficit, Lee et al. ${ }^{7}$ showed better outcomes in patients with AS and DISH than in the control patients; $43 \%$ and $44 \%$ versus $25 \%$ respectively. In our series, there was an improvement in the neurological status in both de novo ASIA D lesions to normal neurological function, while $71.4 \%$ of those ASIA A showed no improvement. Thus, $44 \%$ of those who suffered neurologic damage de novo at the time of the fall showed some improvement after the surgical intervention.

Our patients were hospitalized for a mean period of 52 days. Westerveld et al. ${ }^{1}$ found no difference in hospitalization periods among these patients. However, only $5 \%$ of their patients were admitted in Intensive Care Units, contrasting with $41 \%$ in our series.

In this study we included only surgically treated patients, although one was initially treated conservatively for 2 months. In $29 \%$ of patients a combined approach was chosen, with a 2-stage procedure in one patient. Lee et al. ${ }^{7}$ also demonstrated a combined approach rate of $29 \%$ in AS patients, contrasting with $5.9 \%$ in controls.

One patient needed a total of 7 surgeries after recurrent wound dehiscence with a combined management by plastic surgery. $\mathrm{He}$ was the only one who was diagnosed after a fall from a chair that resulted in ASIA A in a previously asymptomatic independent man.

Morbidity and mortality tend to be worse in patients with ankylosed spines compared to the general population. Pirouzmand ${ }^{14}$ reported a $16.7 \%$ case-fatality rate after traumatic spinal fractures. In our series $18 \%$ of patients died in the in-hospital postoperative period. While in general population studies, most fatalities occur as a result of in high-speed trauma, most mortalities in patients with $\mathrm{AS}$ and DISH occur after minor trauma.

A significant impact in daily activities after injury is also usually reported. Of the $71 \%$ of our patients that were completely independent prior to the fracture, only half of them remain independent. According to the Rankin scale, $35 \%$ were classified as asymptomatic and without disability at time of discharge. Schiefer et al. ${ }^{13}$ found only $1.1 \%$ of patients with this classification. They also demonstrated $76.1 \%$ poor outcomes (mRS 4-6), while in our series, this figure was 35\%.

Westerveld et al. ${ }^{8}$ described general complications such as postoperative wound infections, deep venous thrombosis, pneumonia and respiratory insufficiency as frequently reported complications in both AS and DISH. In our study, around half of the patients developed dysautonomic episodes and/or respiratory tract infections. Other relatively frequent complications included the need for additional surgical interventions or re-hospitalization, death, wound dehiscence and pain described as moderate or greater.

Limitations of our study include the relatively small sample size and the retrospective study design. The number of losses to followup and the short periods available preclude effective assessment on long-term postoperative complications and neurologic outcomes. These include patients who were discharged to skilled facilities or acute rehabilitation centers.

The main goal of this study was to evaluate the outcomes and complications in surgically treated patients with an ankylosed spine who had sustained a vertebral fracture. Secondarily, we aimed to alert physicians to the importance of early diagnosis of ankylosed spines, in order to apply injury prevention strategies. These patients are not only more susceptible to falls caused by restricted motion, but are also prone to more severe lesions that are commonly underdiagnosed. Even after presentation, they are still at higher risk of neurologic deterioration and have higher rates of morbidity and mortality.

\section{CONCLUSIONS}

- Patients with an ankylosed spine disease are at higher risk for fracture even after minor trauma, and these fractures are located predominantly in the cervical spine.

- Physicians must retain a high suspicion in the event of any trauma in an ankylosed spine, and should conduct an adequate assessment in order to avoid delays and patient deterioration.

- New back pain in ankylosed spine patients should be assumed to be caused by a fracture until proven otherwise, in order to avoid delays in presentation that could lead to significant worsening in neurologic function.

- Patients with fractures in ankylosed spinal segments present greater neurologic deficits at admission, which, in the majority of patients, do not improve after surgical treatment.

- Due to neurologic deficits, patients with ankylosed spine fractures are at high risk of dysautonomic episodes.

The surgical treatment of these conditions is effective as it allows improvement of the patient's neurological status, either by anterior, posterior or combined approaches, depending on the assessment of each individual patient.

- Patients with ankylosed spine disease who suffer a spinal fracture present higher morbidity and mortality, as well as a higher risk of serious postoperative complications. 
- A significant percentage of patients surgically treated for ankylosed spine fractures is admitted to an Intensive Care Unit during their hospital stay.

- Ankylosed spine fractures have significant implications in patients' functional ambulatory status, leading to a need for assistance in activities of daily living in previously independent individuals.

Policies to prevent falls should be implemented, as they can drastically change patients' outcome, neurologic function and independence for activities of daily living.

All authors declare no potential conflict of interest related to this article.

CONTRIBUTION OF THE AUTHORS: Each author made significant individual contributions to this manuscript. MACS: structuring, data analysis and writing. DVBRL: data analysis and revision. JDS: structuring, performing the surgeries and data analysis. MECRS: performing the surgeries and data analysis. NSMN: intellectual concept, performing the surgeries, and revision.

\section{REFERENCES}

1. Westerveld LA, van Bemmel JC, Dhert WJ, Oner FC, Verlaan JJ. Clinical outcome after traumatic spinal fractures in patients with ankylosing spinal disorders compared with control patients. Spine J. 2014;14(5):729-40.

2. Novella Navarro M, Munoz Gomez MM, Santiago FR, Alvarez ER. Uncommon localization of pathologic vertebral fracture in ankylosing spondylitis. Joint Bone Spine. 2015:82(5):371.

3. Vargaonkar GS, Singh VK, Kashyap A, Kumar R. Double level Chance-type fractures of spine in ankylosing spondylitis. Chin J Traumatol. 2014;17(6):361-3.

4. Gazi Boyaci M, Tunay K, Rakip U, Karademir M, Karavelioglu E. Ankylosing spondylitis: A cause of death after minor trauma. Joint Bone Spine. 2016;83(4):456.

5. Fatemi G, Gensler LS, Learch TJ, Weisman MH. Spine fractures in ankylosing spondylitis: a case report and review of imaging as well as predisposing factors to falls and fractures. Semin Arthritis Rheum. 2014:44(1):20-4.

6. El Tecle NE, Abode-lyamah KO, Hitchon PW, Dahdaleh NS. Management of spinal fractures in patients with ankylosing spondylitis. Clin Neurol Neurosurg. 2015;139:177-82

7. Lee CK, Yoon DH, Kim KN, Yi S, Shin DA, Kim B, et al. Characteristics of Cervica Spine Trauma in Patients with Ankylosing Spondylitis and Ossification of the Posterior Longitudinal Ligament. World Neurosurg. 2016;96:202-8.

8. Westerveld LA, Verlaan JJ, Oner FC. Spinal fractures in patients with ankylosing spinal dis- orders: a systematic review of the literature on treatment, neurological status and complications. Eur Spine J. 2009;18(2):145-56.

9. Alves PL, Martins DE, Ueta RH, Del Curto D, Wajchenberg M, Puertas EB. Options for surgical treatment of cervical fractures in patients with spondylotic spine: a case series and review of the literature. J Med Case Rep. 2015;9:234.

10. Sapkas G, Kateros K, Papadakis SA, Galanakos S, Brilakis E, Machairas G, et al. Surgical outcome after spinal fractures in patients with ankylosing spondylitis. BMC Musculoskelet Disord. 2009;10:96.

11. Maynard Jr FM, Bracken MB, Creasey G, Ditunno Jr JF, Donovan WH, Ducker TB, et al. International Standards for Neurological and Functional Classification of Spinal Cord Injury. American Spinal Injury Association. Spinal Cord. 1997;35(5):266-74.

12. Bonita R, Beaglehole R. Recovery of motor function after stroke. Stroke. 1988:19(12):1497-500

13. Schiefer TK, Milligan BD, Bracken CD, Jacob JT, Krauss WE, Pichelmann MA, et al. In-hospital neurologic deterioration following fractures of the ankylosed spine: a single-institution experience. World Neurosurg. 2015;83(5):775-83.

14. Pirouzmand F. Epidemiological trends of spine and spinal cord injuries in the largest $\mathrm{Ca}$ nadian adult trauma center from 1986 to 2006. J Neurosurg Spine. 2010;12(2):131-40.

15. Leucht $P$, Fischer K, Muhr G, Mueller EJ. Epidemiology of traumatic spine fractures. Injury. 2009;40(2):166-72.

Appendix. Patients' baseline data.

\begin{tabular}{|c|c|c|c|c|c|c|c|}
\hline \multirow{2}{*}{$\begin{array}{l}\# \\
1\end{array}$} & \multirow{2}{*}{$\begin{array}{c}\text { Age (years) } \\
53\end{array}$} & \multirow{2}{*}{$\begin{array}{c}\text { Sex } \\
M\end{array}$} & \multirow{2}{*}{$\begin{array}{c}\text { Mechanism of injury } \\
\text { Fall from standing height }\end{array}$} & \multirow{2}{*}{\begin{tabular}{|c|} 
Level of Fracture \\
C5-C6 \\
\end{tabular}} & \multicolumn{2}{|c|}{$\begin{array}{c}\text { Neurological status } \\
\text { preoperatively and } \\
\text { postoperatively (ASIA) }\end{array}$} & \multirow{2}{*}{$\begin{array}{c}\text { Instrumentation / Levels of fusion } \\
\text { Anterior / C5-C6 }\end{array}$} \\
\hline & & & & & $E$ & $E$ & \\
\hline 2 & 53 & $\mathrm{M}$ & Fall from more than standing height & C5-T6 & A & A & Posterior / C4-T9 \\
\hline 3 & 80 & M & Fall from more than standing height & C6-T2 & $\mathrm{D}$ & $\mathrm{E}$ & $\begin{array}{c}\text { Posterior + Anterior / } \\
\text { C5-T2 } \\
\end{array}$ \\
\hline 4 & 73 & $\mathrm{M}$ & Fall from standing height & T9 & $E$ & $\mathrm{E}$ & Posterior / T6-T12 \\
\hline 5 & 68 & M & Fall from standing height & C6-C7 & A & A & $\begin{array}{c}\text { Anterior + Posterior / } \\
\text { C4-T3 } \\
\end{array}$ \\
\hline 6 & 83 & $\mathrm{M}$ & Fall from standing height & $\mathrm{C} 6-\mathrm{C} 7$ & A & A & Posterior / C4-T2 \\
\hline 7 & 85 & $\mathrm{M}$ & Fall from standing height & $\mathrm{C} 4-\mathrm{T} 1$ & $E$ & $E$ & Posterior / C4-T2 \\
\hline 8 & 65 & $\mathrm{M}$ & Fall from standing height & T11-T12 & $E$ & $E$ & Posterior / T9-L2 \\
\hline 9 & 57 & $\mathrm{M}$ & Fall from standing height & $\mathrm{C} 6-\mathrm{C} 7$ & $\mathrm{D}$ & $\mathrm{E}$ & Posterior / C5-T1 \\
\hline 10 & 61 & $\mathrm{M}$ & Fall from standing height & $\mathrm{C5}-\mathrm{C} 6$ & $\mathrm{D}$ & $\mathrm{D}$ & Anterior / C4-C7 \\
\hline 11 & 47 & $\mathrm{M}$ & Fall from more than standing height & $\mathrm{C} 2-\mathrm{C} 5$ & A & A & Anterior / C3-C5 \\
\hline 12 & 61 & $\mathrm{M}$ & Fall from standing height & T10-T11 & $E$ & $\mathrm{E}$ & Posterior / T9-T12 \\
\hline 13 & 77 & $\mathrm{M}$ & Vehicle collision: low-speed & C7 & $E$ & $\mathrm{E}$ & Posterior / C4-C6/T1-T2 \\
\hline 14 & 68 & $\mathrm{M}$ & Fall from standing height & $\mathrm{C5}-\mathrm{C7}$ & $\mathrm{D}$ & $\mathrm{D}$ & Anterior + Posterior / C4-C6/T1-T2 \\
\hline 15 & 81 & M & Fall from standing height & $\mathrm{C7}$ & A & C & $\begin{array}{c}\text { Anterior + Posterior / } \\
\text { C4-T1 }\end{array}$ \\
\hline 16 & 87 & M & $\begin{array}{c}\text { Vehicle collision: } \\
\text { high-speed }\end{array}$ & C7 & A & A & Posterior / C5-T2 \\
\hline 17 & 70 & M & $\begin{array}{c}\text { Vehicle collision: } \\
\text { high-speed }\end{array}$ & C4-C5 & $A$ & B & Anterior + Posterior / C3-C6 \\
\hline
\end{tabular}

